\title{
Molecular genetics of human primary microcephaly: an overview
}

\author{
Muhammad Faheem', Muhammad Imran Naseer ${ }^{2,3^{*}}$, Mahmood Rasool ${ }^{2,3}$, Adeel G Chaudhary², \\ Taha A Kumosani 1,4, Asad Muhammad Ilyas ${ }^{1}$, Peter Natesan Pushparaj ${ }^{2,3}$, Farid Ahmed ${ }^{2,3}$, Hussain A Algahtani ${ }^{5}$, \\ Mohammad H Al-Qahtani ${ }^{2,3}$, Hasan Saleh Jamal ${ }^{6}$
}

From 2nd International Genomic Medicine Conference (IGMC 2013)

Jeddah, Kingdom of Saudi Arabia. 24-27 November 2013

\begin{abstract}
Autosomal recessive primary microcephaly $(\mathrm{MCPH})$ is a neurodevelopmental disorder that is characterised by microcephaly present at birth and non-progressive mental retardation. Microcephaly is the outcome of a smaller but architecturally normal brain; the cerebral cortex exhibits a significant decrease in size. MCPH is a neurogenic mitotic disorder, though affected patients demonstrate normal neuronal migration, neuronal apoptosis and neural function. Twelve MCPH loci (MCPH1-MCPH12) have been mapped to date from various populations around the world and contain the following genes: Microcephalin, WDR62, CDK5RAP2, CASC5, ASPM, CENPJ, STIL, CEP135, CEP152, ZNF335, PHC1 and CDK6. It is predicted that MCPH gene mutations may lead to the disease phenotype due to a disturbed mitotic spindle orientation, premature chromosomal condensation, signalling response as a result of damaged DNA, microtubule dynamics, transcriptional control or a few other hidden centrosomal mechanisms that can regulate the number of neurons produced by neuronal precursor cells. Additional findings have further elucidated the microcephaly aetiology and pathophysiology, which has informed the clinical management of families suffering from MCPH. The provision of molecular diagnosis and genetic counselling may help to decrease the frequency of this disorder.
\end{abstract}

\section{Introduction}

In this review article, we discuss the clinical manifestations of autosomal recessive primary microcephaly $(\mathrm{MCPH})$, its incidence, and molecular genetics, including a comprehensive review of the twelve known mapped loci (MCPH1-MCPH12). Further, we review the corresponding genes and the proteins encoded by these genes, their possible role in the developing brain and reported mutations of these genes. In addition, the potential for these genes to perform various cognitive roles during human brain evolutionary processes is discussed.

\section{Clinical features of MCPH}

Microcephaly is characterised by a reduced occipitofrontal circumference (OFC) of the head that is at least 4 standard

\footnotetext{
* Correspondence: mimrannaseer@yahoo.com

${ }^{2}$ Center of Excellence in Genomic Medicine Research, King Abdulaziz University, KSA

Full list of author information is available at the end of the article
}

deviations (SD) and is caused by congenital insufficiency during fetal brain development, which chiefly affects the cerebral cortex. The current clinical definition of MCPH is as follows: A: a head circumference $(\mathrm{HC})$ of at least $4 \mathrm{SD}$ below the age- and sex-matched means [1]; B: intellectual impairment that is not related to a neurological finding, such as spasticity or progressive cognitive decline [1]; and C: most MCPH patients are of a normal height, weight, and appearance and have normal chromosome analysis and brain scan results [2,3]. The only exception of this is observed in patients with mutations in the microcephalin gene who have a clinically defined short stature and abnormal chromosome analysis results [4-6]. Microcephaly in $\mathrm{MCPH}$ is primary, is evident by the 32 nd week of gestation, can be observed at the time of birth and is non-progressive $[7,8]$. HC or OFC is the most common diagnostic tool used for $\mathrm{MCPH}$. Based on the findings of several studies conducted on more than 200 families worldwide, it is believed that the specific physical 
appearance of patients linked to each $\mathrm{MCPH}$ locus is indistinguishable [9-12]. Additionally, the chromosomal analysis for most MCPH patients was reportedly normal [9]. However, recent studies supported by modern neurodiagnostic modalities, such as computed tomography (CT) scan and magnetic resonance imaging (MRI), have significantly increased our knowledge regarding the discernible clinical presentations of $\mathrm{MCPH}$ and have expanded the definition of MCPH based on phenotype [7,13,14].

\section{Molecular Genetics of MCPH MCPH Incidence}

Primary microcephaly is present at birth and is a static developmental anomaly, whereas secondary microcephaly develops postnatally and is a progressive neurodegenerative condition. Primary microcephaly is very rare, and the rate of incidence is estimated to be 1 in 30,000 in Japan [15] and 1 in 250,000 in Holland [16]. The incidence is increased up to 1 in 10,000 in regions where marriages between cousins are common [1,6]. The birth incidence of primary microcephaly differs from 1.3 to $150 / 100,000$, depending on the population type and consanguineous populations [17].

\section{$\mathrm{MCPH}$ Inheritance}

$\mathrm{MCPH}$ is inherited in an autosomal recessive pattern in which both copies of the gene in each cell have mutations. Individuals with MCPH inherit one copy of the mutated gene from each parent, but the parents typically do not demonstrate any signs or symptoms of the condition [18].

\section{Genes in MCPH}

$\mathrm{MCPH}$ is a neurogenic mitotic disorder that does not occur due to abnormal neuronal migration or neural apoptosis. Rather, it develops because all of the identified MCPH genes are expressed in the neuroepithelium; the phenotypic features and brain scans of MCPH patients reveal a smaller than average brain size. Brain size during birth is determined by both the proliferation rate and cell death rate during neurogenesis. The majority of neurons originate from neural progenitors, which are the predominant cells of the neuroepithelium (NE) lining the brain ventricles [1]. The precise mitotic activity of neuronal progenitor cells was first described in fly neuroblasts: symmetrical cell divisions with mitotic spindles oriented in the neuroepithelium plane produce two neuronal progenitor cells, whereas asymmetric cell division occurs when the mitotic spindles are perpendicularly oriented toward the neuroepithelium and results in one postmitotic neuron and one progenitor cell [1]. Because the timing of these divisions during development is critical for the final number of neurons, any change in its regulation could lead to cortical disorders, such as microcephaly [19]. MCPH exhibits genetic heterogeneity, and to date, twelve loci (MCPH1-MCPH12) have been associated with this condition [20]. A comprehensive review is outlined below of the twelve $\mathrm{MCPH}$ genes that carry mutations, their possible functions in causing the disease (Table 1), various mutations in people of different ethnic backgrounds (Table 2) and animal model studies (Table 3) of the $\mathrm{MCPH}$ genes.

\section{1- Microcephalin (MCPH1)}

MCPH1 encodes the BRCT (BRCA1 C-terminus) domain-containing protein microcephalin; microcephalin contains three BRCT domains, which are evolutionarily conserved phospho-peptide-interacting amino acid tandem repeat domains and are significant in cell cycle control. MCPH1 is characterised by a congenital decrease in brain size, especially in the cerebral cortex. The microcephalin gene is localised on chromosome $8 \mathrm{p} 23$, is composed of 14 exons and 835 amino acids, and has a genome size of $241,905 \mathrm{bp}$, with three already known isoforms and an 8,032 bp open reading frame $[17,21]$. The first documented MCPH1 gene mutation was observed in Pakistani families [21]; additionally, a large deletion mutation covering the first 6 exons of the microcephalin gene was reported in an Iranian family that exhibited autosomal recessive mental retardation and mild microcephaly [22]. An observed missense mutation in MCPH1 demonstrated a less severe cellular phenotype and mild microcephaly [5,7]. Later, a mutation in the same gene was identified in patients with microcephaly disorder, a misregulated chromosomal condensation termed premature chromosome condensation (PCC) syndrome and short stature [23,24]. A higher expression of this gene was observed in the fetal mouse brain during neurogenesis, especially in ganglionic eminences and lateral ventricles [21]. It was revealed that both MCPH1 and the PCC syndrome are allelic disorders originating from mutations within the same gene [4]. This protein is also involved in DNA damageinduced cellular responses, chromosomal condensation and during G2/M checkpoint arrest through maintaining the inhibitory cyclin-dependent kinase phosphorylation [6]. Further studies revealed that the consequences of MCPH1 deficiency in Drosophila include a slow mitotic entry, PCC, mitotic entrance with non-replicated DNA, non-coordinated centrosome, genome instability and a detached centrosome. Additionally, mitotic arrest was observed in Drosophila cells with deficient MCPH1 $[25,26]$. It was also observed that because of the influence on premature neurogenic formation, the progenitors with reduced MCPH1 increased the production of early born neurons, which comprise the deep layers (IV-VI), and decreased the late-born neurons, which produce the thinner outer cortex layer (II-III). However, neuronal migration is not affected due to MCPH1 deletion [27]. The successful generation of a mouse model 
Table 1 Summary of known MCPH genes, their location and role.

\begin{tabular}{|c|c|c|c|c|c|}
\hline Locus & Gene & Cytoband & Cellular location & Role/effect on brain development & References \\
\hline $\mathrm{MCPH} 1$ & Microcephalin & $8 p 23.1$ & Nucleus & $\begin{array}{c}\text { Involved in chromosomal condensation, reduced MCPH1 } \\
\text { enhances the production of early born neurons, which comprise } \\
\text { deep layers (IV-VI), and reduces the late-born neurons, which } \\
\text { produce the thinner outer cortex layer (II-III). }\end{array}$ & {$[6,27]$} \\
\hline $\mathrm{MCPH} 2$ & WDR62 & $19 q 13.12$ & $\begin{array}{l}\text { Nucleus/Centrosomes/ } \\
\text { Neuronal precursors/Post- } \\
\text { mitotic neurons }\end{array}$ & $\begin{array}{c}\text { Cerebral cortical development, proliferation and migration of } \\
\text { neuronal precursors, mutation in WDR62 affects its role in } \\
\text { proliferating and migrating neural precursors and causes severe } \\
\text { brain malformations. }\end{array}$ & {$[13,30]$} \\
\hline $\mathrm{MCPH} 3$ & CDK5RAP2 & $9 q 33.2$ & Centrosome & $\begin{array}{c}\text { Regulates microtubule function, mutation in CDK5RAP2 reduces } \\
\text { the progenitor pool/decreases the number of neurons and } \\
\text { reduces cell survival. }\end{array}$ & {$[35,36,38,88]$} \\
\hline $\mathrm{MCPH} 4$ & CASC5 & $15 q 15.1$ & Kinetochore & $\begin{array}{c}\text { Vital for the spindle checkpoint of the mitotic cycle, CASC5 } \\
\text { underscores the role of kinetochore integrity in the proper } \\
\text { volumetric development of the human brain. }\end{array}$ & {$[40,41]$} \\
\hline MCPH5 & ASPM & $1 \mathrm{q} 31.3$ & Pericentrosomal & $\begin{array}{l}\text { Orientation of mitotic spindles during embryonic neurogenesis, } \\
\text { ASPM mutations can decrease the size of the brain by influencing } \\
\text { the orientation of the mitotic spindle. }\end{array}$ & {$[57,54,14]$} \\
\hline MCPH6 & CENPJ & $13 q 12.12$ & $\begin{array}{l}\text { Centrosome/ } \\
\text { neuroepithelium of the } \\
\text { frontal cortex }\end{array}$ & $\begin{array}{c}\text { Controls centriole length/microtubule function, its deletion causes } \\
\text { an increased incidence of multiple spindle poles, apoptosis and } \\
\text { mitosis arrest }\end{array}$ & {$[63,64]$} \\
\hline $\mathrm{MCPH} 7$ & STIL & $1 \mathrm{p} 33$ & Pericentrosomal & $\begin{array}{l}\text { Apoptosis regulator/cell cycle progression, its mutation in } \\
\text { zebrafish causes an embryonic lethal defect, and STIL knockout } \\
\text { mice (Sil-/-) exhibit numerous developmental abnormalities/ } \\
\text { decreased size/defective midline neural tube. }\end{array}$ & {$[72,69,68]$} \\
\hline MCPH8 & CEP135 & $4 q 12$ & Centrosome & $\begin{array}{c}\text { Maintains organisation/structure of the centrosome, CEP135 } \\
\text { knockdown showed decreased growth rate/disorganised } \\
\text { microtubules. }\end{array}$ & {$[72,70,20]$} \\
\hline MCPH9 & CEP152 & $15 q 21.1$ & Centrosome & $\begin{array}{c}\text { Centriole duplication/shape to cell/polarity/motility, conversion of } \\
\text { glutamine into proline disturbs potential coiled-coiled protein } \\
\text { domain/reduced head size. }\end{array}$ & {$[76,77]$} \\
\hline $\mathrm{MCPH} 10$ & ZNF335 & $20 q 13.12$ & Nucleus & $\begin{array}{c}\text { Progenitor cell division/differentiation, mutated ZNF335 gene } \\
\text { causes degeneration of neurons, knockdown of ZNF335 caused a } \\
\text { small brain size with an absent cortex/disrupted proliferation and } \\
\text { differentiation of neuronal cells. }\end{array}$ & [78] \\
\hline $\mathrm{MCPH} 11$ & $\mathrm{PHCl}$ & $12 p 13.31$ & Nucleus & $\begin{array}{l}\text { Regulates cell cycle, } \mathrm{PHC1} \text { mutation highlights the role of } \\
\text { chromatin remodelling in the pathogenesis of Primary } \\
\text { Microcephaly. }\end{array}$ & {$[80]$} \\
\hline $\mathrm{MCPH} 12$ & CDK6 & $7 q 21.11$ & Cytoplasmic/nuclear & $\begin{array}{l}\text { Controls cell cycle/organises microtubules, CDK6 mutation affects } \\
\text { apical neuronal precursor cells proliferation/reduces progenitor } \\
\text { pool/decreases neuronal production/primary microcephaly. }\end{array}$ & [83] \\
\hline
\end{tabular}

Abbreviations. MCPH: Autosomal recessive primary microcephaly; MCPH1: Microcephalin; WDR62: WD repeat-containing protein 62; CDK5RAP2: Cyclin dependent kinase-5 regulatory subunit associated protein; CASC5: Cancer susceptibility candidate-5; ASPM: Abnormal spindle like primary microcephaly; CENPJ: Centromereassociated protein J; STIL:SCL/TAL1 interrupting locus; CEP135: Centrosomal protein 135; CEP152: Centrosomal protein 152; ZNF335: Zinc Finger Protein 335; PHC1: Polyhomeotic-like protein 1; CDK6: Cyclin-dependent kinase 6.

for MCPH1-related primary microcephaly revealed misregulated mitotic chromosome condensation due to defective MCPH1 function and a reduced skull size $[28,29]$.

\section{2- WDR62 (MCPH2)}

The WDR62 gene is localised inside the MCPH2 locus at chromosome 19q13.12 and has 32 exons and a genomic size of 50,230 bp [30]. WDR62 is a WD40 repeat-containing protein expressed in neuronal precursors and postmitotic neurons in the developing brain and is localised in the spindle poles of dividing cells. Phenotypic variations of WDR62 advocate its key role in numerous aspects of cerebral cortical development [13]; it has been linked with severe brain malformations. A previous study revealed five homozygous WDR62 mutations, including deletions and premature terminations, in patients of Turkish origin suffering from severe brain malformations and microcephaly [30]. A 7.5 Mb locus on chromosome 19q13.12 composed of 148 genes was recognised in two families via genomewide linkage analysis. Additionally, high throughput sequencing of associated genes in each family produced more than 4,000 DNA variants harbouring deleterious changes involving a single gene WDR62. Additionally, six mutations were observed in the WDR62 gene through targeted high throughput sequence analysis in six families suffering from a congenital microcephaly syndrome and diverse defects in cerebral cortical architecture [13]. 
Table 2 Number of reported mutations in MCPH genes in families of different ethnic backgrounds worldwide.

\begin{tabular}{|c|c|c|c|c|c|c|c|}
\hline \multirow{2}{*}{$\begin{array}{l}\text { MCPH } \\
\text { genes }\end{array}$} & \multirow{2}{*}{$\begin{array}{l}\text { Reported } \\
\text { mutations }\end{array}$} & \multicolumn{4}{|c|}{ Types of mutations } & \multirow[t]{2}{*}{ Ethnicity (families) } & \multirow[t]{2}{*}{ References } \\
\hline & & $\begin{array}{l}\text { Missense/ } \\
\text { nonsense }\end{array}$ & Splicing & $\begin{array}{l}\text { Deletions \& } \\
\text { insertions }\end{array}$ & $\begin{array}{l}\text { Complex } \\
\text { rearrangements }\end{array}$ & & \\
\hline $\mathrm{MCPH} 1$ & 24 & 8 & 1 & 14 & 1 & Iranian (8), Caucasian (1), Pakistani (13) & {$[5,22,51,86,89-91]$} \\
\hline WDR62 & 28 & 14 & 1 & 13 & 0 & $\begin{array}{l}\text { Iranian (3), Turkish (11), Mexican (1), Arab (1), } \\
\text { Pakistan (9) }\end{array}$ & {$[7,13,30,86,91]$} \\
\hline CDKRAP2 & 6 & 3 & 2 & 1 & 0 & Pakistani (2), Somalian (1) & {$[7,32,34,36,92]$} \\
\hline CASC5 & 1 & 1 & 0 & 0 & 0 & Moroccan (3) & [43] \\
\hline ASPM & 104 & 48 & 7 & 48 & 1 & $\begin{array}{l}\text { Iranian (13), Arab (12), Indian (8), European (22), } \\
\text { African (5), Pakistani (60), many sporadic cases. }\end{array}$ & {$[7,14,50,51,86,91,93]$} \\
\hline CENPJ & 5 & 2 & 1 & 2 & 0 & Iranian (5), Pakistani (6) & {$[32,60,61,86,91]$} \\
\hline STIL & 4 & 2 & 1 & 1 & 0 & Iranian (2), Indian (3) & {$[68,86,87]$} \\
\hline CEP135 & 1 & 0 & 0 & 1 & 0 & Pakistani (1) & {$[20]$} \\
\hline CEP152 & 9 & 5 & 2 & 2 & 0 & Pakistani (5), Canadian (3) & {$[77,91,94]$} \\
\hline ZNF335 & 2 & 1 & 1 & 0 & 0 & Arab Israeli (1) & [78] \\
\hline PHCl & 1 & 1 & 0 & 0 & 0 & Saudi Arabian (1) & {$[80]$} \\
\hline CDK6 & 1 & 1 & 0 & 0 & 0 & Pakistani (1) & [83] \\
\hline
\end{tabular}

Abbreviations. MCPH: Autosomal recessive primary microcephaly; MCPH1: Microcephalin; WDR62: WD repeat-containing protein 62; CDK5RAP2: Cyclin dependent kinase-5 regulatory subunit associated protein; CASC5: Cancer susceptibility candidate-5; ASPM: Abnormal spindle like primary microcephaly; CENPJ: Centromereassociated protein J; STIL:SCL/TAL1 interrupting locus; CEP135:Centrosomal protein 135; CEP152: Centrosomal protein 152; ZNF335: Zinc Finger Protein 335; PHC1: Polyhomeotic-like protein 1; CDK6: Cyclin-dependent kinase 6.

Table 3 MCPH animal models.

\begin{tabular}{|c|c|c|c|}
\hline $\begin{array}{l}\text { MCPH } \\
\text { gene }\end{array}$ & $\begin{array}{l}\text { Animal orthologs of } \\
\text { human gene }\end{array}$ & Animal model & References \\
\hline$\overline{M C P H 1}$ & $\begin{array}{l}\text { mcph1-/- (Drosophila/ } \\
\text { mice) }\end{array}$ & $\begin{array}{l}\text { Premature condensation of chromosome, non-coordinated centrosome, genome instability, } \\
\text { detached centrosome, changes in cell cycle progression and defects in DNA damage repair, } \\
\text { misregulated mitotic chromosome condensation. }\end{array}$ & {$[25,26,29]$} \\
\hline CDK5RAP2 & Cnn-/- (Drosophila) & $\begin{array}{l}\text { Centrosome dysfunction causes connection loss between centrosomes and pericentriolar matrix. } \\
\text { Only subtle defects of asymmetric divisions; the sizes of the observed brains were normal. }\end{array}$ & [39] \\
\hline ASPM & $\begin{array}{l}\text { asp-/- (Drosophila) } \\
\text { Aspm-/-(mice) }\end{array}$ & $\begin{array}{l}\text { The Drosophila asp gene is vital for both the organisation and binding together of microtubules } \\
\text { at the spindle poles and to focus the poles of the mitotic spindles during mitosis and meiosis. } \\
\text { Two mutant mouse lines showed that mutations in ASPM decreased the brain size in mice. }\end{array}$ & {$[56-58]$} \\
\hline CENPJ & $\begin{array}{l}\text { Sas-4-/-(Drosophila, c. } \\
\text { elegans) }\end{array}$ & $\begin{array}{c}\text { Centrioles are lost due to damage of the CENPJ orthologue dsas-4 in Drosophila; in contrast, the } \\
\text { knockout flies can live until adulthood but have weak coordination and lower viability. The } \\
\text { morphological development of mutant flies is normal without cilia or flagella, but they die in } \\
\text { early life. }\end{array}$ & {$[65,66]$} \\
\hline STIL & STIL Sil-/-(mice) & $\begin{array}{l}\text { STIL knockout mice (Sil-/-) exhibit numerous developmental abnormalities in embryonic days } \\
\text { E7.5-8.5 and die after E10.5, the phenotype of the mutant mice is characterised by decreased } \\
\text { brain size, restricted development, defective midline neural tube, abnormal development, and } \\
\text { enhanced apoptosis; the observed mutants were embryonically lethal. }\end{array}$ & [71] \\
\hline CEP135 & $\begin{array}{l}\text { Bldio-/- } \\
\text { (Chlamydomonas) }\end{array}$ & $\begin{array}{c}\text { In Chlamydomonas, CEP135 ortholog Bld10p mutants (b/d10) demonstrated abnormal interphase } \\
\text { microtubules and mitotic spindles, defects during cell division and a significant decrease in the } \\
\text { growth rate. }\end{array}$ & {$[73]$} \\
\hline CEP152 & $\begin{array}{l}\text { Orthologous (Drosophila } \\
\text { asterless; asl) }\end{array}$ & $\begin{array}{c}\text { CEP152 is the putative mammalian orthologue of Drosophila asterless, mutations in which affect } \\
\text { mitosis in the fly. }\end{array}$ & [77] \\
\hline ZNF335 & $\begin{array}{l}\text { Orthologue (mice; } \\
\text { ZNF335) }\end{array}$ & $\begin{array}{c}\text { Knockdown of ZNF335 caused a small brain size with an absent cortex and disrupted the } \\
\text { proliferation and differentiation of neuronal cells. It was observed that knockdown of the ZNF335 } \\
\text { ortholog in mice (ZFP335) resulted in early embryonic lethality at day E7.5. Conditional } \\
\text { knockdown of ZNF335 in mouse cortical cells resulted in a small brain with a fundamentally } \\
\text { absent cortex with deficient cortical neurons. }\end{array}$ & {$[78]$} \\
\hline
\end{tabular}

Abbreviations. MCPH1: Microcephalin; CDK5RAP2: Cyclin dependent kinase-5 regulatory subunit associated protein; ASPM: Abnormal spindle like primary microcephaly; CENPJ: Centromere-associated protein J; STIL: SCL/TAL1 interrupting locus; CEP135: Centrosomal protein 135; CEP152: Centrosomal protein 152; ZNF335: Zinc Finger Protein 335. 
Published observations from multiple groups have shown that WDR62 is mainly nuclear in its location and lacks any apparent association with the centrosomes. In contrast to this, other findings have shown that the WDR62 expression is similar to $A S P M$, which is also a $\mathrm{MCPH}$ protein focused at the spindle poles in neuronal precursor cells [30]. Another study further confirmed that disturbance of the centrosome integrity and spindle defects are the key players in developing $\mathrm{MCPH} 2$ microcephaly [31]. In HeLa cells, WDR62 accumulates in the centrosome or nucleus in a cell cycle-dependent manner; siRNA knockdown of WDR62 in cortical progenitors decreased their proliferation, caused defective spindle orientation, and reduced the centrosome integrity, displacement from the spindle poles and late mitotic development [31].

\section{3- CDK5RAP2 (MCPH3)}

Homozygous mutations of cyclin-dependent kinase 5 regulatory subunit-associated protein-2 (CDK5RAP2) have been recognised as the basis of $\mathrm{MCPH} 3$ [32]. This protein is composed of 38 exons encoding 1,893 amino acids. Three CDK5RAP2 mutations (two in Pakistani families; one in a Somalian patient) have been described; 1: a nonsense mutation in exon 4 (246T>A); 2: the A to $G$ transition in intron $26(4005-15 \mathrm{~A}>\mathrm{G})$ produces a novel splice acceptor site, frame shift and a premature stop codon; and 3: a nonsense mutation in exon $8(700 \mathrm{G}>\mathrm{T})$. All of these mutations result in a truncated protein with CDK5RAP2 functional loss [32-34]. CDK5RAP2 is strongly linked with the centrosome, Golgi apparatus, and microtubules and is chiefly present in the neural progenitors of the ventricular and sub-ventricular zones of an immature brain; it has also been observed in glial cells and early born neurons and is progressively down regulated as the brain matures $[35,36]$. CDK5RAP2 is also essential in the regulation of the spindle checkpoint; its loss causes chromosomal missegregation and decreased spindle checkpoint protein expression through binding with their promoters and transcriptional regulation in HeLa cells [37]. A model of the microcephaly phenotype due to a mutation in CDK5RAP2 causes a premature transition from symmetric to asymmetric neuronal progenitor cell division with a consequent reduction of the progenitor pool, decreased neurons and reduced cell survival $[35,38]$. Centrosome dysfunction, which is known as centrosome 'rocketing', was observed within the cells because of the connection loss between the centrosomes and pericentriolar matrix in the human CDK5RAP2 ortholog 'centrosomin'-deficient Drosophila embryos (cnn-/-). Only subtle asymmetric division defects were observed in 'centrosomin'-deficient Drosophila embryos (cnn-/-), and the brain sizes were normal [39].

\section{4- CASC5 (MCPH4)}

CASC5 is a $265 \mathrm{KDa}$ large protein that belongs to the conserved KMN protein network and permits chromosomal kinetochore docking to the microtubule. Its location adjacent to the kinetochore remains constant from G2 until late anaphase; proper docking is very important for sufficient sister chromatid segregation at anaphase and is vital for the spindle checkpoint of the mitotic cycle [40,41]. A CASC5 mutation on the MCPH4 locus with an LOD score of $>6$ in $\mathrm{MCPH}$ patients from three consanguineous families has been reported. This mutation enhanced the skipping of exon 18, produced a frame shift and premature stop codon in exon 19, followed by truncation of the predicted protein. Mutation $6125 \mathrm{G}>\mathrm{A}$ in $C A S C 5$ covers the amino acids from 1,981 to 2,108 , which interact with ZWINT-1, whereas the CASC5 C-terminus is important for binding with NSL1 and the MIS12 complex in a downstream portion of the mutation. Therefore, the loss of exon 18 and the resulting frame shift and truncation lead to a functional loss of CASC5[40,42]. This protein is also upregulated in the ventricular zone of the human fetal brain and interacts with BUBR1, ZWINT-1 and MIS12 through the $\mathrm{N}$-terminal domain, which can be truncated due to mutation [43]. A transcriptome analysis through RNA sequencing of the germinal zone of the human fetal neocortex at 13-16 gestational weeks revealed a higher expression of CASC5 in the ventricle zone compared the sub ventricle zone and cortical plate; this finding further confirmed the effect of mutated CASC5 on proliferating cells in the ventricle zone that cause microcephaly $[43,44]$. Further analysis by CASC5 siRNA knockdown in HeLa cells revealed chromosomal misalignment and the premature entry of the cells into mitosis; this defect causes improper symmetrical and asymmetrical division, which results in inefficient proliferation, inappropriate neuronal number and abnormal brain size [45].

\section{5- ASPM (MCPH5)}

Abnormal spindle-like primary microcephaly $(A S P M)$, which is homologous to Drosophila melanogaster, is important for the normal functioning of the mitotic spindle in embryonic neuroblasts harbouring MCPH5 locus [14]. It consists of 62,567 bp with a 10,906 bp ORF, 28 exons and 3,477 amino acids, with a putative microtubule-interacting domain at the $\mathrm{N}$-terminus $[46,47]$, calponin homology domain, 81 isoleucine glutamine motifs acting as a calmodulin binding domain $[14,48,49]$, and a C-terminus without any identified domains [50]. Studies have revealed four novel mutations of this gene in 33 families from Pakistan [51]. ASPM gene mutations truncate the protein and include deletion, single base pair change, duplication and variation in the intronic region. Additionally, substantial numbers of the observed ASPM mutations are compound heterozygous $[10,52]$. In neurogenesis, this gene is mainly expressed in the cerebral cortical ventricular zone and proliferation zones of the medial and lateral ganglion [14]. Another study showed the localisation of this protein at the 
spindles, and its knockdown by siRNA revealed reduced proliferative symmetric division in the mouse developing neocortex [53]. Studies have shown that because of neurosphere differentiation, $A S P M$ is downregulated in mice; additionally, neurosphere proliferation and self-renewal was decreased as a result of $A S P M$ knockdown [54]. Morpholino-mediated knockdown of $A S P M$ in zebrafish resulted in a significant reduction in head size [55]. Drosophila asp gene mutants were the first to be known as having a mini-brain; this asp gene is known to be vital for both the organisation and binding of microtubules at the spindle poles and its ability to focus the poles of mitotic spindles during mitosis and meiosis [56,57]. Additionally, two mutant mouse lines were generated from gene trap cells for the study of ASPM function in the development of the cerebral cortex. The results showed that mutations in $A S P M$ decreased the size of brain in mice [58]. It is therefore concluded that $A S P M$ mutations can decrease the size of the brain by influencing the orientation of the mitotic spindle and can decrease the neuronal cells by affecting the asymmetrical to symmetrical cell division ratios [54,57].

\section{6- CENPJ (MCPH6)}

Mutations in the centromere-associated protein J (CENP) gene harboured in the MCPH6 locus on human chromosome 13q12.2 have been reported to cause primary microcephaly [32]. This gene is composed of 40,672 bp with a 5,187 bp ORF [46] and 17 exons, which encode a protein of 1,338 amino acids; it contains 5 coiled-coiled domains, many protein phosphorylation sites, 21 nonamer G-box repeats in the C-terminal domain and, $\mathrm{C}$-terminal to that, contains a leucine zipper motif [32,59]. In total, four mutations were identified in the CENPJ gene: one mutation in one Brazilian family, [32] and one mutation in two Pakistani families [32]. Later, another Pakistani family showed the deletion of four consecutive nucleotides (TCAG) in the $11^{\text {th }}$ exon of the CENPJ gene, which causes a frame shift and a premature termination codon $19 \mathrm{bp}$ downstream in the same exon that is predicted to add six amino acids downstream of the mutation [60]. The fourth mutation is a splicing mutation in the CENPJ gene that was identified in Seckel syndrome patients [61]. This protein is mainly expressed in the neuroepithelium of the frontal cortex at the beginning of neurogenesis [32]. Depletion of this protein disturbs the centrosome integrity, and cells deficient in CENPJ become arrested during mitosis, with multipolar spindles [62]. An in vitro analysis showed that this protein can impede microtubule nucleation and depolymerisation, predicting a role for CENPJ in directing the centrosomal assembly of microtubules [63]. Prior studies have also shown that CENPJ deletion by siRNA causes the enhancement of multiple spindle poles, apoptosis and mitosis arrest [64]. Centrioles are lost due to damage of the CENPJ orthologue dsas-4 in Drosophila; in contrast, the knockout flies can live until adulthood but have weak coordination and lower viability [65]. The morphological development of mutant flies is normal without cilia or flagella, but they die in early life [66]. Sas-4 is a centriole protein controlling centrosome organisation in C. elegans, and its involvement has been confirmed in the duplication of centrosome fluorescence recovery after photo bleaching (FRAP). CENPJ regulates the centriole length throughout biogenesis, with possible involvement in the accurate recruitment of centriolar microtubules [67].

\section{7- STIL (MCPH7)}

The $S C L / T A L 1$ interrupting locus $(S T I L)$ gene was identified at the seventh locus for MCPH, spanning 63,018 bp with a 5,225 bp ORF, 20 exons and 1,287 residues in a full-length cytosolic protein of $150 \mathrm{kDa}$; it also contains a putative nuclear localisation signal and $\mathrm{C}$-terminal domain $[17,68]$. Three mutations causing protein truncation were observed in members of five Indian families in an $8.39 \mathrm{Mb}$ region of chromosome 1p33-p32.3 [68]. The expression of this gene is observed throughout the cytosol but mainly in the peri-nuclear region, with an essential role in mitotic entry (G2-M phase), apoptosis regulation and centrosome function [68]. STIL is a primary response gene that is ubiquitously expressed in proliferating cells and in early embryonic development [69,70]. Studies of zebrafish have revealed that STIL has an important role in the duplication of centrosomes and in the organisation of mitotic spindles. STIL mutation in zebrafish causes an embryonic lethal defect [69], and STIL knockout mice (Sil-/-) exhibit numerous developmental abnormalities at embryonic day E7.5-8.5 and die after E10.5. The phenotype of the mutant mice is described as a decreased size, restricted development, defective midline neural tube, abnormal development, enhanced apoptosis, reduced proliferation and abnormal expression of numerous essential genes, including lefty- 2 and nodal. Additionally, the observed mutants were embryonically lethal [71].

\section{8- CEP135 (MCPH8)}

Centrosomal protein (CEP135) is encoded by the CEP135 gene, is composed of 26 exons and 1,140 amino acids and is a conserved $\alpha$ helical protein observed throughout the cell cycle at the centrosome. As a centrosomal component, this protein gives more strength to the centrosomes. A truncated mutation in CEP135 was identified in a Pakistani family at locus $4 \mathrm{q} 12$ that caused microcephaly. A deletion mutation 970delC changes glutamine to serine at position 324, followed by the premature termination of a codon. Considering the mutation's position and the affected protein; the truncated mutation is definitely not compatible with the normal function of CEP135[20]. 
Studies by electron microscopy revealed that CEP135 is associated with pericentriolar material, an electron-dense material around the centrioles. In interphase, the mitotic spindles are disorganised due to an RNAi-mediated decreased amount of CEP135 in the cells, which suggests that CEP135 maintains the organisation and structure of the centrosomes and microtubules [72]. In Chlamydomonas, CEP135 ortholog bld10p mutants (bld10) demonstrated abnormal interphase microtubules and mitotic spindles, defects during cell division and a significant decrease in the growth rate [73]; additionally, CEP135 knockdown in $\mathrm{CHO}$ cells showed a decreased growth rate [72]. The C-terminal domain of CEP135 contains an interacting site for its two binding partners, the $50 \mathrm{kDa}$ dynactin complex subunit (p50) and C-Nap1. Due to the truncation of CEP135, both $\mathrm{p} 50$ and C-Nap1 are released, promoting the decomposition of centrosomes and the premature splitting of the centrosomes, respectively $[74,75]$.

\section{9- CEP152 (MCPH9)}

CEP152 is an important $152 \mathrm{kDa}$ centrosome protein that organises the microtubules of animal cells and has an essential role in giving shape to the cell, polarity, motility and cell division [76]. The CEP152 gene is localised to the MCPH4 locus at chromosome 15q21.1; recently, microcephaly due to a mutation in the CEP152 gene was designated as MCPH9 [43,77]. Human CEP152 is an ortholog of the Drosophila asterless (asl) gene, contains 72,835 bp and 1,710 amino acids encoding a $152 \mathrm{kDa}$ protein [77]. Three families with one microcephalic child each were identified from a subpopulation of eastern Canadian. A homozygosity analysis of two of the families by genome-wide dense SNP genotyping revealed the locus 15q21.1 chromosome. Exon sequencing of the candidate genes identified a non-conserved amino acid conversion into a highly conserved CEP152 residue [77]. One mutation converts glutamine into proline, which is anticipated to be pathogenic and can disturb a potential coiled-coiled protein domain. The other mutation causes protein truncation by eliminating a portion predicted to be a coding region from the $\mathrm{C}$-terminal domain [77]. A greater head size reduction was observed in compound heterozygous females compared with missense homozygous females. The truncated protein causes a nonsense-mediated decay of the mutated transcript; studies have also revealed during a functional assay to observe the subcellular localisation that the wild type CEP152-GFP fusion protein can be identified in $\gamma$-tubulin-co structures [77]. Mutant CEP152 flagged with GFP failed to colocalize with the $\gamma$-tubulin, which further confirmed the pathogenicity due to this mutation [77].

\section{0- ZNF335 (MCPH10)}

The ZNF335 gene encodes a component of the vertebrate-specific, trithorax H3K4-methylation chromatin remodelling complex, which regulates neuronal gene expression and cell fate [78]. MCPH10 was identified due to a mutation in the ZNF335 gene in affected members of an Arab Israeli family. This mutation was recognised in a homozygous 3332G-A transition in exon 20 of the ZNF335 gene and resulted in an Arg1111 to His $(\mathrm{R} 1111 \mathrm{H})$ substitution at a conserved residue in the 13th zinc-finger domain. This mutation was identified at the final position of a splice donor site that disturbed normal splicing, leading to an abnormally large transcript that included introns 19 and 20 with a predicted premature termination [78]. Patient cells also showed severely reduced levels of ZNF335 protein, but a few residual transcripts were identified. Cellular studies revealed that ZNF335 binds to the chromatin remodelling complex, including H3K4 methyl transferases that can regulate the expression of specific genes in various pathways; the complex is analogous to the TrxG (trithorax) complex in Drosophila. Mutations in nBAF, one of the neural-specific chromatin regulatory complexes, affected proliferation, revealing that it is related to microcephaly [79]. Insufficiency of the ZNF335 gene causes the degeneration of neurons, which makes it different and much more severe compared with other microcephaly syndromes that are well linked to postnatal survival. In vitro and in vivo mouse models showed that knockdown of ZNF335 caused a small brain size with an absent cortex and disrupted the proliferation and differentiation of neuronal cells [78]. It was observed that knockdown of the ZNF335 ortholog in mice (ZFP335) resulted in early embryonic lethality at day E7.5. Conditional knockdown of ZNF335 in mouse cortical cells resulted in a small brain with a fundamentally absent cortex with deficient cortical neurons. Knockdown of ZNF335 in mouse neuronal progenitor cells caused reduced proliferation and self-renewal due to premature cell cycle exit. Similar findings were observed in an in vivo embryonic mouse model using in utero electroporation to target ZNF335 in cortical progenitor cells. ZNF335 depletion resulted in abnormal neuronal cell orientation and radial glia with disorganised dendritic outgrowth. [78].

\section{1- PHC1 (MCPH11)}

Primary microcephaly-11 (MCPH11) is caused by homozygous mutation in the PHC1 gene on chromosome 12p13. A 12-year-old girl and her 6-year-old brother, who were born to related Saudi parents, suffered from primary microcephaly (-5.8 and $-4.3 \mathrm{SD}$, respectively) and low normal cognitive function. The brain MRIs were normal, except for a small brain size. The sister and brother also had short stature (-3.6 SD and -2.3 SD, respectively) [80]. The mutation, which was found by homozygosity mapping combined with exome sequencing, segregated with the disorder and was not found in the dbSNP, Exome Variant 
Server or 1000 Genomes database or in 199 Saudi exomes or 554 Saudi control individuals [80]. A microarray analysis showed that various genes with a role in regulating the cell cycle are dysregulated in the patient cells [80]. Cells with a PHC1 mutation also enhanced the geminin expression, which was recapitulated in RNAi experiments in control and patient cells in which $\mathrm{PHCl}$ was ectopically expressed. Because geminin has a recognised role in controlling the cell cycle [81,82], PM pathogenesis could be partly due to abnormalities in the cell cycle that are the result of accumulated geminin. The patient cells also showed an increase in DNA damage and defective DNA repair in response to irradiation and abnormal cell cycle activity consistent with reduced proliferative activity compared with controls. These defects were associated with abnormalities in chromatin regulation and could be rescued in patient cells by the overexpression of wild type $P H C 1[80]$.

\section{2- CDK6 (MCPH12)}

The cyclin-dependent kinase $6(C D K 6)$ protein controls the cell cycle and differentiation of different cell types. Prior studies showed a genetic defect through a novel $\mathrm{MCPH}$ locus on the long arm of chromosome 7 (MCPH12). This mutated gene causes disorganisation of the microtubules and spindles, distorted nuclei, and supernumerary centrosomes. Furthermore, this role was confirmed by knockdown cells and cells expressing the CDK6 mutant allele, whereas the decreased proliferation observed in the patient and knockdown cells reinforced its already described role in controlling the cell cycle [83]. CDK6 mutation also affects apical neuronal precursor cell proliferation and produces an imbalance between symmetric and asymmetric cell division, which results in a progenitor pool reduction that could be the reason of decreased neuronal production and, finally primary microcephaly [83]. A study of a consanguineous eight-generation Pakistani family with ten microcephalic children showed a new MCPH locus at HSA 7q21.11-q21.3 [83]. Most related candidate genes in this region showed a homozygous single nucleotide substitution, $589 \mathrm{G}>\mathrm{A}$, in $C D K 6$, which encodes cyclin-dependent kinase 6 . This mutation leads to an abnormal mitotic morphology and has an effect on cellular localisation because patient primary fibroblasts failed in recruiting CDK6 to the centrosome during the mitosis process [84]. This finding was confirmed by another study that showed a lower proliferation capacity of CDK6 patient primary fibroblasts and knockdown cells; CDK6 also has a significant role in differentiating various cell types [85].

\section{Mutation spectrum of MCPH Genes in Middle Eastern and Saudi populations}

A total of approximately forty-three families have been reported with mutations in MCPH gene from the Middle
Eastern and, especially, Saudi Arabian region: twenty-eight from Iran, fourteen from Arab countries, three from Morocco and one from Saudi Arabia $[22,43,80,86,87]$. More specifically, eight Iranian families have been reported with mutations in the $\mathrm{MCPH} 1$ gene, thirteen with mutations in the ASPM gene, five with mutations in the CENJP gene and two with mutations in the STIL gene $[22,86,87]$. CASC5 gene mutation have been found in $\mathrm{MCPH}$ patients from three consanguineous Moroccan families with a homozygous missense mutation $6125 \mathrm{G}>\mathrm{A}$ that leads to an amino acid substitution Met2041Ile; this substitution is predicted to inactivate an exonic splicing enhancer (ESE), leading to an abnormal transcript lacking exon 18 [43]. A total of thirteen Arab families have been reported with mutations in the ASPM and ZNF335 genes. A homozygous $2974 \mathrm{C}>\mathrm{T}$ mutation in the $P H C 1$ gene on chromosome 12p13 was reported in a 12-year-old girl and her 6year-old brother born to related Saudi parents who were suffering from primary microcephaly [80].

\section{Conclusions}

Cognitive capabilities are reduced with a substantial decrease in brain size in $\mathrm{MCPH}$ patients, whose brain sizes decrease to one third compared with its original size with a substantial cognitive decline. There are twelve known genes that cause this neurodevelopmental disorder, and recent evidence suggests that $\mathrm{MCPH}$ is possibly a primary disorder of neurogenic mitosis. With the progress of $\mathrm{MCPH}$ gene identification, prenatal diagnosis (detects a disorder recurrence), postnatal diagnosis (differentiates the disorder from various differential diagnosis) and carrier testing (for consanguineous families in which the disease is known to occur) are increasingly available for patients. The successful creation of mammalian models for $\mathrm{MCPH}$ has enabled researchers to further add to the knowledge regarding the aetiology and pathophysiology of $\mathrm{MCPH}$. Better genotyping, neuro-physiological and neuroimaging testing, together with the creation of genetically homogeneous groups of patients, would benefit the identification of exact genotype phenotype correlations. Mutational screening in different $\mathrm{MCPH}$ families from the Middle East and especially Saudi Arabia would help in genetic counselling and prenatal diagnosis for MCPH and would eventually enable us to reduce the incidence of $\mathrm{MCPH}$ in a highly consanguineous population. Additionally, these studies have increased our understanding of the control of neuronal production by neural stem cells and how this has been modulated by evolution to control the brain sizes of different species.

\section{Abbreviations}

$\mathrm{MCPH}$ : Autosomal recessive primary microcephaly; OFC: Occipitofrontal circumference; SD: Standard deviations; HC: Head circumference; PCC: 
Premature chromosome condensation; MRI: Magnetic Resonance Imaging; WDR62: WD repeat-containing protein 62; CDK5RAP2: Cyclin dependent kinase-5 regulatory subunit associated protein-2; CASC5: Cancer susceptibility candidate-5; ASPM: Abnormal spindle like primary microcephaly; CENPJ: Centromere-associated protein J; FRAP: Fluorescence recovery after photo bleaching; CEP: Centrosomal protein; ZNF335: Zinc Finger Protein 335; PHC1: Polyhomeotic-like protein 1; CDK6: Cyclin-dependent kinase 6.

\section{Competing interests}

The authors declare that they have no conflicts of interest.

\section{Authors' contributions}

MF, MIN and PNP wrote the manuscript. MR, AGC, TAK, MHA, AMI, HSJ and FA edited the final version. All authors read and approved the final version of the manuscript.

\section{Acknowledgments}

The authors gratefully acknowledge the King Abdulaziz City for Science and Technology (KACST) Large Grant No\# (APR-34-13) and KACST Project Code: Project No.8-MED120-3 for providing the funds and for its continual generous support during the course of this important project, KSA. MR is supported by KACST strategic project code "12-MED3078-03; PNP is supported by KACST strategic project "12-BIO2719-03 and 12-BIO2267-03; FA supported by KACST strategic project code "09-BIO693-03; HSJ is supported by KACST project code "8-MED 120-3".

\section{Declarations}

This article has been published as part of BMC Medical Genomics Volume 8 Supplement 1, 2015: Selected articles from the 2nd International Genomic Medical Conference (IGMC 2013): Medical Genomics. The full contents of the supplement are available online at http://www.biomedcentral.com/ bmcmedgenomics/supplements/8/S1

\section{Authors' details}

${ }^{1}$ Department of Biochemistry, Faculty of Science, King Abdulaziz University, KSA. ${ }^{2}$ Center of Excellence in Genomic Medicine Research, King Abdulaziz University, KSA. ${ }^{3}$ KACST Technology Innovation Center in Personalized Medicine, King Abdulaziz University, Jeddah, Kingdom of Saudi Arabia. ${ }^{4}$ King Fahd Medical Research Center, King Abdulaziz University, KSA. ${ }^{5}$ King Saud bin Abdulaziz University for Health Sciences, KSA. ${ }^{6}$ Department of Obstetrics and Gynecology, King Abdulaziz University Hospital, Jeddah, Kingdom of Saudi Arabia.

Published: 15 January 2015

\section{References}

1. Finlay BL, Darlington RB: Linked regularities in the development and evolution of mammalian brains. Science 1995, 268(5217):1578-1584.

2. McCreary BD, Rossiter JP, Robertson DM: Recessive (true) microcephaly: a case report with neuropathological observations. Journal of intellectual disability research : JIDR 1996, 40(Pt 1):66-70.

3. Mochida GH, Walsh CA: Molecular genetics of human microcephaly. Current opinion in neurology 2001, 14(2):151-156.

4. Trimborn M, Bell SM, Felix C, Rashid Y, Jafri H, Griffiths PD, Neumann LM, Krebs A, Reis A, Sperling K, et al: Mutations in microcephalin cause aberrant regulation of chromosome condensation. American journal of human genetics 2004, 75(2):261-266.

5. Trimborn M, Richter R, Sternberg N, Gavvovidis I, Schindler D, Jackson AP, Prott EC, Sperling K, Gillessen-Kaesbach G, Neitzel H: The first missense alteration in the $\mathrm{MCPH} 1$ gene causes autosomal recessive microcephaly with an extremely mild cellular and clinical phenotype. Human mutation 2005, 26(5):496.

6. Cox J, Jackson AP, Bond J, Woods CG: What primary microcephaly can tell us about brain growth. Trends in molecular medicine 2006, 12(8):358-366.

7. Woods CG, Bond J, Enard W: Autosomal recessive primary microcephaly $(\mathrm{MCPH})$ : a review of clinical, molecular, and evolutionary findings. American journal of human genetics 2005, 76(5):717-728.

8. Desir J, Abramowicz M, Tunca Y: Novel mutations in prenatal diagnosis of primary microcephaly. Prenatal diagnosis 2006, 26(10):989.

9. Roberts E, Hampshire DJ, Pattison L, Springell K, Jafri H, Corry P, Mannon J, Rashid Y, Crow Y, Bond J, et al: Autosomal recessive primary microcephaly: an analysis of locus heterogeneity and phenotypic variation. Journal of medical genetics 2002, 39(10):718-721.

10. Muhammad F, Mahmood Baig S, Hansen L, Sajid Hussain M, Anjum Inayat I, Aslam M, Anver Qureshi J, Toilat M, Kirst E, Wajid M, et al: Compound heterozygous ASPM mutations in Pakistani MCPH families. American journal of medical genetics Part A 2009, 149A(5):926-930.

11. Gul A, Tariq M, Khan MN, Hassan MJ, Ali G, Ahmad W: Novel proteintruncating mutations in the ASPM gene in families with autosomal recessive primary microcephaly. Journal of neurogenetics 2007, 21(3):153-163.

12. Nicholas AK, Swanson EA, Cox JJ, Karbani G, Malik S, Springell K, Hampshire D, Ahmed M, Bond J, Di Benedetto D, et al: The molecular landscape of ASPM mutations in primary microcephaly. Journal of medical genetics 2009, 46(4):249-253.

13. Yu TW, Mochida GH, Tischfield DJ, Sgaier SK, Flores-Sarnat L, Sergi CM, Topcu M, McDonald MT, Barry BJ, Felie JM, et al: Mutations in WDR62, encoding a centrosome-associated protein, cause microcephaly with simplified gyri and abnormal cortical architecture. Nature genetics 2010, 42(11):1015-1020.

14. Bond J, Roberts E, Mochida GH, Hampshire DJ, Scott S, Askham JM, Springell K, Mahadevan M, Crow YJ, Markham AF, et al: ASPM is a major determinant of cerebral cortical size. Nature genetics 2002, 32(2):316-320.

15. Komai T, Kishimoto K, Ozaki Y: Genetic study of microcephaly based on Japanese material. American journal of human genetics 1955, 7(1):51-65.

16. Van Den Bosch J: Microcephaly in the Netherlands: a clinical and genetical study. Annals of human genetics 1959, 23(2):91-116.

17. Kaindl AM, Passemard S, Kumar P, Kraemer N, Issa L, Zwirner A, Gerard B, Verloes A, Mani S, Gressens P: Many roads lead to primary autosomal recessive microcephaly. Progress in neurobiology 2010, 90(3):363-383.

18. Kloepfer HW, Platou RV, Hansche WJ: Manifestations of a Recessive Gene for Microcephaly in a Population Isolate. Journal de genetique humaine 1964, 13:52-59.

19. Rakic P: Specification of cerebral cortical areas. Science 1988 241(4862):170-176.

20. Hussain MS, Baig SM, Neumann S, Nurnberg G, Farooq M, Ahmad I, Alef T, Hennies HC, Technau M, Altmuller J, et al: A truncating mutation of CEP135 causes primary microcephaly and disturbed centrosomal function. American journal of human genetics 2012, 90(5):871-878.

21. Jackson AP, Eastwood H, Bell SM, Adu J, Toomes C, Carr IM, Roberts E, Hampshire DJ, Crow YJ, Mighell AJ, et al: Identification of microcephalin, a protein implicated in determining the size of the human brain. American journal of human genetics 2002, 71(1):136-142.

22. Garshasbi M, Motazacker MM, Kahrizi K, Behjati F, Abedini SS, Nieh SE, Firouzabadi SG, Becker C, Ruschendorf F, Nurnberg P, et al: SNP arraybased homozygosity mapping reveals $\mathrm{MCPH} 1$ deletion in family with autosomal recessive mental retardation and mild microcephaly. Human genetics 2006, 118(6):708-715.

23. Ponting C, Jackson AP: Evolution of primary microcephaly genes and the enlargement of primate brains. Current opinion in genetics \& development 2005, 15(3):241-248.

24. $\mathrm{Xu} \mathrm{X}$, Lee J, Stern DF: Microcephalin is a DNA damage response protein involved in regulation of CHK1 and BRCA1. The Journal of biological chemistry 2004, 279(33):34091-34094.

25. Brunk K, Vernay B, Griffith E, Reynolds NL, Strutt D, Ingham PW, Jackson AP: Microcephalin coordinates mitosis in the syncytial Drosophila embryo. Journal of cell science 2007, 120(Pt 20):3578-3588.

26. Rickmyre JL, Dasgupta S, Ooi DL, Keel J, Lee E, Kirschner MW, Waddell S, Lee LA: The Drosophila homolog of MCPH1, a human microcephaly gene, is required for genomic stability in the early embryo. Journal of cell science 2007, 120(Pt 20):3565-3577.

27. Zhou ZW, Tapias A, Bruhn C, Gruber R, Sukchev M, Wang ZQ: DNA damage response in microcephaly development of $\mathrm{MCPH} 1$ mouse model. DNA repair 2013, 12(8):645-655.

28. Chen J, Ingham N, Clare S, Raisen C, Vancollie VE, Ismail O, McIntyre RE, Tsang SH, Mahajan VB, Dougan G, et al: Mcph1-deficient mice reveal a role for MCPH1 in otitis media. PloS one 2013, 8(3):e58156.

29. Trimborn M, Ghani M, Walther DJ, Dopatka M, Dutrannoy V, Busche A, Meyer F, Nowak S, Nowak J, Zabel C, et al: Establishment of a mouse model with misregulated chromosome condensation due to defective Mcph1 function. PloS one 2010, 5(2):e9242.

30. Bilguvar K, Ozturk AK, Louvi A, Kwan KY, Choi M, Tatli B, Yalnizoglu D, Tuysuz B, Caglayan AO, Gokben S, et al: Whole-exome sequencing 
identifies recessive WDR62 mutations in severe brain malformations. Nature 2010, 467(7312):207-210.

31. Farag HG, Froehler S, Oexle K, Ravindran E, Schindler D, Staab T, Huebner A, Kraemer N, Chen W, Kaindl AM: Abnormal centrosome and spindle morphology in a patient with autosomal recessive primary microcephaly type 2 due to compound heterozygous WDR62 gene mutations. Orphanet journal of rare diseases 2013, 8(1):178.

32. Bond J, Roberts E, Springell K, Lizarraga SB, Scott S, Higgins J, Hampshire DJ, Morrison EE, Leal GF, Silva EO, et al: A centrosomal mechanism involving CDK5RAP2 and CENPJ controls brain size. Nature genetics 2005, 37(4):353-355.

33. Hassan MJ, Khurshid M, Azeem Z, John P, Ali G, Chishti MS, Ahmad W: Previously described sequence variant in CDK5RAP2 gene in a Pakistani family with autosomal recessive primary microcephaly. BMC medical genetics 2007, 8:58

34. Pagnamenta AT, Murray JE, Yoon G, Sadighi Akha E, Harrison V, Bicknell LS, Ajilogba K, Stewart H, Kini U, Taylor JC, et al: A novel nonsense CDK5RAP2 mutation in a Somali child with primary microcephaly and sensorineural hearing loss. American journal of medical genetics Part A 2012, 158A(10):2577-2582.

35. Kraemer N, Issa L, Hauck SC, Mani S, Ninnemann O, Kaindl AM: What's the hype about CDK5RAP2? Cellular and molecular life sciences: CMLS 2011, 68(10):1719-1736.

36. Issa L, Kraemer N, Rickert CH, Sifringer M, Ninnemann O, StoltenburgDidinger G, Kaindl AM: CDK5RAP2 expression during murine and human brain development correlates with pathology in primary autosomal recessive microcephaly. Cerebral cortex 2013, 23(9):2245-2260.

37. Zhang X, Liu D, Lv S, Wang H, Zhong X, Liu B, Wang B, Liao J, Li J, Pfeifer GP, et al: CDK5RAP2 is required for spindle checkpoint function. Cell cycle 2009, 8(8):1206-1216.

38. Megraw TL, Sharkey JT, Nowakowski RS: Cdk5rap2 exposes the centrosomal root of microcephaly syndromes. Trends in cell biology 2011, 21(8):470-480.

39. Lucas EP, Raff JW: Maintaining the proper connection between the centrioles and the pericentriolar matrix requires Drosophila centrosomin. The Journal of cell biology 2007, 178(5):725-732.

40. Kiyomitsu T, Obuse C, Yanagida M: Human Blinkin/AF15q14 is required for chromosome alignment and the mitotic checkpoint through direct interaction with Bub1 and BubR1. Developmental cell 2007, 13(5):663-676.

41. Cheeseman IM, Hori T, Fukagawa T, Desai A: KNL1 and the CENP-H/I/K complex coordinately direct kinetochore assembly in vertebrates. Molecular biology of the cell 2008, 19(2):587-594.

42. Petrovic A, Pasqualato S, Dube P, Krenn V, Santaguida S, Cittaro D, Monzani S, Massimiliano L, Keller J, Tarricone A, et al: The MIS12 complex is a protein interaction hub for outer kinetochore assembly. The Journal of cell biology 2010, 190(5):835-852.

43. Genin A, Desir J, Lambert N, Biervliet M, Van Der Aa N, Pierquin G, Killian A, Tosi M, Urbina M, Lefort A, et al: Kinetochore KMN network gene CASC5 mutated in primary microcephaly. Human molecular genetics 2012, 21(24):5306-5317.

44. Fietz SA, Lachmann R, Brandl H, Kircher M, Samusik N, Schroder R, Lakshmanaperumal N, Henry I, Vogt J, Riehn A, et al: Transcriptomes of germinal zones of human and mouse fetal neocortex suggest a role of extracellular matrix in progenitor self-renewal. Proceedings of the National Academy of Sciences of the United States of America 2012, 109(29):11836-11841.

45. Gruber R, Zhou Z, Sukchev M, Joerss T, Frappart PO, Wang ZQ: MCPH1 regulates the neuroprogenitor division mode by coupling the centrosomal cycle with mitotic entry through the Chk1-Cdc25 pathway. Nature cell biology 2011, 13(11):1325-1334

46. Saunders RD, Avides MC, Howard T, Gonzalez C, Glover DM: The Drosophila gene abnormal spindle encodes a novel microtubuleassociated protein that associates with the polar regions of the mitotic spindle. The Journal of cell biology 1997, 137(4):881-890.

47. Ponting CP: A novel domain suggests a ciliary function for ASPM, a brain size determining gene. Bioinformatics 2006, 22(9):1031-1035.

48. Craig $R$, Norbury C: The novel murine calmodulin-binding protein Sha1 disrupts mitotic spindle and replication checkpoint functions in fission yeast. Journal of cell science 1998, 111(Pt 24):3609-3619.

49. Kouprina N, Pavlicek A, Collins NK, Nakano M, Noskov VN, Ohzeki J, Mochida GH, Risinger Jl, Goldsmith P, Gunsior M, et al: The microcephaly
ASPM gene is expressed in proliferating tissues and encodes for a mitotic spindle protein. Human molecular genetics 2005, 14(15):2155-2165.

50. Bond J, Scott S, Hampshire DJ, Springell K, Corry P, Abramowicz MJ, Mochida GH, Hennekam RC, Maher ER, Fryns JP, et al: Protein-truncating mutations in ASPM cause variable reduction in brain size. American journal of human genetics 2003, 73(5):1170-1177.

51. Gul A, Hassan MJ, Mahmood S, Chen W, Rahmani S, Naseer MI, Dellefave L, Muhammad N, Rafiq MA, Ansar M, et al: Genetic studies of autosomal recessive primary microcephaly in 33 Pakistani families: Novel sequence variants in ASPM gene. Neurogenetics 2006, 7(2):105-110.

52. Saadi A, Borck G, Boddaert N, Chekkour MC, Imessaoudene B, Munnich A, Colleaux L, Chaouch M: Compound heterozygous ASPM mutations associated with microcephaly and simplified cortical gyration in a consanguineous Algerian family. European journal of medical genetics 2009, 52(4):180-184.

53. Paramasivam M, Chang YJ, LoTurco JJ: ASPM and citron kinase co-localize to the midbody ring during cytokinesis. Cell cycle 2007, 6(13):1605-1612.

54. Thornton GK, Woods CG: Primary microcephaly: do all roads lead to Rome? Trends in genetics: TIG 2009, 25(11):501-510.

55. Kim HT, Lee MS, Choi JH, Jung JY, Ahn DG, Yeo SY, Choi DK, Kim CH: The microcephaly gene aspm is involved in brain development in zebrafish Biochemical and biophysical research communications 2011, 409(4):640-644.

56. Riparbelli MG, Callaini G, Glover DM, Avides Mdo C: A requirement for the Abnormal Spindle protein to organise microtubules of the central spindle for cytokinesis in Drosophila. Journal of cell science 2002, 115(Pt 5):913-922.

57. do Carmo Avides M, Glover DM: Abnormal spindle protein, Asp, and the integrity of mitotic centrosomal microtubule organizing centers. Science 1999, 283(5408):1733-1735

58. Pulvers JN, Bryk J, Fish JL, Wilsch-Brauninger M, Arai Y, Schreier D, Naumann R, Helppi J, Habermann B, Vogt J, et al: Mutations in mouse Aspm (abnormal spindle-like microcephaly associated) cause not only microcephaly but also major defects in the germline. Proceedings of the National Academy of Sciences of the United States of America 2010, 107(38):16595-16600.

59. Hung $L Y$, Tang $C J$, Tang TK: Protein 4.1 R-135 interacts with a novel centrosomal protein (CPAP) which is associated with the gamma-tubulin complex. Molecular and cellular biology 2000, 20(20):7813-7825.

60. Gul A, Hassan MJ, Hussain S, Raza SI, Chishti MS, Ahmad W: A novel deletion mutation in CENPJ gene in a Pakistani family with autosomal recessive primary microcephaly. Journal of human genetics 2006, 51(9):760-764.

61. Al-Dosari MS, Shaheen R, Colak D, Alkuraya FS: Novel CENPJ mutation causes Seckel syndrome. Journal of medical genetics 2010, 47(6):411-414.

62. Cho JH, Chang CJ, Chen CY, Tang TK: Depletion of CPAP by RNAi disrupts centrosome integrity and induces multipolar spindles. Biochemical and biophysical research communications 2006, 339(3):742-747.

63. Hung LY, Chen HL, Chang CW, Li BR, Tang TK: Identification of a novel microtubule-destabilizing motif in CPAP that binds to tubulin heterodimers and inhibits microtubule assembly. Molecular biology of the cell 2004, 15(6):2697-2706.

64. Koyanagi M, Hijikata M, Watashi K, Masui O, Shimotohno K: Centrosomal P4.1-associated protein is a new member of transcriptional coactivators for nuclear factor-kappaB. The Journal of biological chemistry 2005, 280(13):12430-12437.

65. Basto R, Lau J, Vinogradova T, Gardiol A, Woods CG, Khodjakov A, Raff JW: Flies without centrioles. Cell 2006, 125(7):1375-1386.

66. Stevens NR, Raposo AA, Basto R, St Johnston D, Raff JW: From stem cell to embryo without centrioles. Current biology : CB 2007, 17(17):1498-1503.

67. Kirkham M, Muller-Reichert T, Oegema K, Grill S, Hyman AA: SAS-4 is a C. elegans centriolar protein that controls centrosome size. Cell 2003, 112(4):575-587.

68. Kumar A, Girimaji SC, Duvvari MR, Blanton SH: Mutations in STIL, encoding a pericentriolar and centrosomal protein, cause primary microcephaly. American journal of human genetics 2009, 84(2):286-290.

69. Pfaff KL, Straub CT, Chiang K, Bear DM, Zhou Y, Zon LI: The zebra fish cassiopeia mutant reveals that SIL is required for mitotic spindle organization. Molecular and cellular biology 2007, 27(16):5887-5897.

70. Campaner S, Kaldis P, Izraeli S, Kirsch IR: Sil phosphorylation in a Pin1 binding domain affects the duration of the spindle checkpoint. Molecular and cellular biology 2005, 25(15):6660-6672. 
71. Izraeli S, Lowe LA, Bertness VL, Good DJ, Dorward DW, Kirsch IR, Kuehn MR: The SIL gene is required for mouse embryonic axial development and left-right specification. Nature 1999, 399(6737):691-694.

72. Ohta T, Essner R, Ryu JH, Palazzo RE, Uetake Y, Kuriyama R: Characterization of Cep135, a novel coiled-coil centrosomal protein involved in microtubule organization in mammalian cells. The Journal of cell biology 2002, 156(1):87-99.

73. Matsuura K, Lefebvre PA, Kamiya R, Hirono M: Bld10p, a novel protein essential for basal body assembly in Chlamydomonas: localization to the cartwheel, the first ninefold symmetrical structure appearing during assembly. The Journal of cell biology 2004, 165(5):663-671.

74. Uetake Y, Terada Y, Matuliene J, Kuriyama R: Interaction of Cep135 with a p50 dynactin subunit in mammalian centrosomes. Cell motility and the cytoskeleton 2004, 58(1):53-66.

75. Kim K, Lee S, Chang J, Rhee K: A novel function of CEP135 as a platform protein of C-NAP1 for its centriolar localization. Experimental cell research 2008, 314(20):3692-3700.

76. Andersen JS, Wilkinson CJ, Mayor T, Mortensen P, Nigg EA, Mann M: Proteomic characterization of the human centrosome by protein correlation profiling. Nature 2003, 426(6966):570-574.

77. Guernsey DL, Jiang H, Hussin J, Arnold M, Bouyakdan K, Perry S, BabineauSturk T, Beis J, Dumas N, Evans SC, et al: Mutations in centrosomal protein CEP152 in primary microcephaly families linked to MCPH4. American journal of human genetics 2010, 87(1):40-51.

78. Yang YJ, Baltus AE, Mathew RS, Murphy EA, Evrony GD, Gonzalez DM, Wang EP, Marshall-Walker CA, Barry BJ, Murn J, et al: Microcephaly gene links trithorax and REST/NRSF to control neural stem cell proliferation and differentiation. Cell 2012, 151(5):1097-1112.

79. Hoyer J, Ekici AB, Endele S, Popp B, Zweier C, Wiesener A, Wohlleber E, Dufke A, Rossier E, Petsch C, et al: Haploinsufficiency of ARID1B, a member of the SWI/SNF-a chromatin-remodeling complex, is a frequent cause of intellectual disability. American journal of human genetics 2012, 90(3):565-572.

80. Awad S, Al-Dosari MS, Al-Yacoub N, Colak D, Salih MA, Alkuraya FS, Poizat C: Mutation in $\mathrm{PHC1}$ implicates chromatin remodeling in primary microcephaly pathogenesis. Human molecular genetics 2013, 22(11):2200-2213.

81. Luo L, Kessel M: Geminin coordinates cell cycle and developmental control. Cell cycle 2004, 3(6):711-714.

82. McGarry TJ, Kirschner MW: Geminin, an inhibitor of DNA replication, is degraded during mitosis. Cell 1998, 93(6):1043-1053.

83. Hussain MS, Baig SM, Neumann S, Peche VS, Szczepanski S, Nurnberg G, Tariq M, Jameel M, Khan TN, Fatima A, et al: CDK6 associates with the centrosome during mitosis and is mutated in a large Pakistani family with primary microcephaly. Human molecular genetics 2013.

84. Grossel MJ, Baker GL, Hinds PW: cdk6 can shorten G(1) phase dependent upon the N-terminal INK4 interaction domain. The Journal of biological chemistry 1999, 274(42):29960-29967.

85. Grossel MJ, Hinds PW: From cell cycle to differentiation: an expanding role for cdk6. Cell cycle 2006, 5(3):266-270.

86. Darvish H, Esmaeeli-Nieh S, Monajemi GB, Mohseni M, GhasemiFirouzabadi S, Abedini SS, Bahman I, Jamali P, Azimi S, Mojahedi F, et al: A clinical and molecular genetic study of 112 Iranian families with primary microcephaly. Journal of medical genetics 2010, 47(12):823-828.

87. Papari E, Bastami M, Farhadi A, Abedini SS, Hosseini M, Bahman I, Mohseni M, Garshasbi M, Moheb LA, Behjati F, et al: Investigation of primary microcephaly in Bushehr province of Iran: novel STIL and ASPM mutations. Clinical genetics 2013, 83(5):488-490.

88. Fong KW, Choi YK, Rattner JB, Qi RZ: CDK5RAP2 is a pericentriolar protein that functions in centrosomal attachment of the gamma-tubulin ring complex. Molecular biology of the cell 2008, 19(1):115-125.

89. Tommerup N, Mortensen E, Nielsen MH, Wegner RD, Schindler D, Mikkelsen M: Chromosomal breakage, endomitosis, endoreduplication, and hypersensitivity toward radiomimetric and alkylating agents: a possible new autosomal recessive mutation in a girl with craniosynostosis and microcephaly. Human genetics 1993, 92(4):339-346.

90. Ghani-Kakhki M, Robinson PN, Morlot S, Mitter D, Trimborn M, Albrecht B, Varon R, Sperling K, Neitzel H: Two Missense Mutations in the Primary Autosomal Recessive Microcephaly Gene MCPH1 Disrupt the Function of the Highly Conserved N-Terminal BRCT Domain of Microcephalin. Molecular syndromology 2012, 3(1):6-13.
91. Sajid Hussain M, Marriam Bakhtiar S, Farooq M, Anjum I, Janzen E, Reza Toliat M, Eiberg H, Kjaer KW, Tommerup N, Noegel AA, et al: Genetic heterogeneity in Pakistani microcephaly families. Clinical genetics 2013, 83(5):446-451.

92. Tan CA, Topper S, Ward Melver C, Stein J, Reeder A, Arndt K, Das S: The first case of CDK5RAP2-related primary microcephaly in a nonconsanguineous patient identified by next generation sequencing. Brain \& development 2014, 36(4):351-355.

93. Passemard S, Titomanlio L, Elmaleh M, Afenjar A, Alessandri JL, Andria G, de Villemeur TB, Boespflug-Tanguy O, Burglen L, Del Giudice E, et al: Expanding the clinical and neuroradiologic phenotype of primary microcephaly due to ASPM mutations. Neurology 2009, 73(12):962-969.

94. Kalay E, Yigit G, Aslan Y, Brown KE, Pohl E, Bicknell LS, Kayserili H, Li Y, Tuysuz B, Nurnberg G, et al: CEP152 is a genome maintenance protein disrupted in Seckel syndrome. Nature genetics 2011, 43(1):23-26.

doi:10.1186/1755-8794-8-S1-S4

Cite this article as: Faheem et al:: Molecular genetics of human primary microcephaly: an overview. BMC Medical Genomics 2015 8(Suppl 1):S4.

\section{Submit your next manuscript to BioMed Central and take full advantage of:}

- Convenient online submission

- Thorough peer review

- No space constraints or color figure charges

- Immediate publication on acceptance

- Inclusion in PubMed, CAS, Scopus and Google Scholar

- Research which is freely available for redistribution
C Biomed Central 